\title{
NEMESÍTHETŐ ACÉLOK ÉS ROZSDAMENTES ACÉLOK PLAZMANITRIDÁLÁSA
}

\section{PLASMA NITRIDING OF TEMPERED STEELS AND STAINLESS STEELS}

\author{
Kovács Dorina ${ }^{1}$, Blücher József ${ }^{2}$, Dobránszky János ${ }^{3}$, Fábián Réka ${ }^{4}$ \\ ${ }^{1,2,4}$ BME Gépészmérnöki Kar, Anyagtudmány és Technológia Tanszék, \\ Magyarország, 1111 Budapest, Müegyetem rakpart 3. \\ 3MTA-BME Kompozittechnológiai Kutatócsoport \\ Magyarország, 1111 Budapest, Müegyetem rakpart 3. \\ Idorina@eik.bme.hu, ${ }^{2}$ jblucher@verzion.net, ${ }^{3}$ dobranszky.janos@eik.bme.hu \\ 4fabianr@eik.bme.hu
}

\begin{abstract}
A plasma-nitriding system was built at the BME Department of Materials Science and Engineering. The aim of this surface treatment equipment is to produce nitrided layers on different steels. The aim of our research work is to analyze with SEM-EDS and XRD the surface of tempered steels and stainless steels after plasma-nitriding. We made specimens in our laboratory and for comparing, at an industrial partner in its equipment. Metallographic and hardness testing and microstructural characterization were performed. Corrosion tests were made on stainless steels to prove the properties of preliminary researches.
\end{abstract}

Keywords: plasma nitriding, tempered steel, stainless steel, corrosion test.

\section{Összefoglalás}

A BME Gépészmérnöki Kar, Anyagtudomány és Technológia Tanszékén új plazmanitridáló berendezés épült. A kutatómunka célja, hogy elsőként nemesíthető acélok, majd ausztenites és duplex korrózióálló acélok kopási tulajdonságait vizsgáljuk a plazmanitridálással létrehozott felületeken. Metallográfiai vizsgálattal, mikrokeménység-méréssel, pásztázó elektronmikroszkóppal és diffraktométeres vizsgálattal elemeztük a felületen kialakult réteg összetételét, vastagságát, keménységét. A mintákat mind ipari, mind laboratóriumi körülmények között plazmanitridáltuk. A rozsdamentes acélokat korróziós tesztnek vetettük alá, melyet az előzetes kutatások alapján értékeltünk. A vizsgálatok után a különböző technológiai változókkal készült mintákat összehasonlítva megállapítottuk, hogy a keménységben eltérés nem mutatkozik, kizárólag a réteg vastagsága eltérő.

Kulcsszavak: plazmanitridálás, nemesithető acélok, rozsdamentes acélok, korróziós vizsgálat.

\section{A plazmanitridálásról}

A plazmanitridálás során kemény, kopásálló réteget lehet létrehozni a felületen. A kis nyomáson bejuttatott gáz a villamos tér hatására az anódként kapcsolt munkadarab és a katódként kapcsolt kemencefal között ionizálódik. A gázatomok gerjesztett állapotba kerülnek, a legrövidebb úton ütköznek egymással, és bombázzák a munka- 
darabot. A nitrogénionok Fe-atomokat választanak le a felületről, melyekkel összekapcsolódva megtapadnak a felületen.

Indulásként a gázteret argon-hidrogén keverékkel töltik fel, a rendszer átöblítése és a munkadarab tisztítása érdekében. Az ionbombázás a felületet porlasztja; e részfolyamat megtisztítja a felületet a rajtamaradt szennyeződésektől, oxidoktól, melyek megakadályozhatják a nitrogén diffúzióját. A többlépcsős tisztítás végeztével nitrogén gázt vezetnek a kamrába. Az ionizáció, azaz a plazma létrejötte után a nitrogénionok bediffundálnak a felületbe, majd nitridet képeznek a vassal [1].

A nitridált réteg két részből áll: egy külső, nagyon kemény, ún. vegyületi vagy fehér rétegből, mely a technológiai tényezőktől és a kezelés idejétől függően $20 \mu \mathrm{m}$ vastag is lehet [2], alatta pedig egy kisebb keménységü, kis mennyiségü oldott nitrogént tartalmazó diffúziós réteg található akár $0,6-0,8 \mathrm{~mm}$-es vastagságban [1-3, 5-7].

\section{Laboratóriumi plazmanitridáló berendezés}

A berendezés (1. ábra) gázterét egy üvegbura képzi, ami kiváló megfigyelési lehetőséget ad a plazmához. A gyors felmelegedés érdekében höárnyékoló pajzsot használunk a mintatartó körül, ami egy köszörült alaplapon helyezkedik el. A gáz- és nagyfeszültségü bevezetés ezen keresztül történik. A kamra nyomását egy vákuumpumpa biztosítja. A berendezés feszültsége 0-800V között állítható.

\section{Célkitűzések}

A kísérletek célja egyrészt, hogy a laboratóriumi és ipari körülmények között készült mintadaraboknak összehasonlítsuk a plazmanitridálással elóállított kemény réteg tulajdonságait; másrészt, hogy megvizsgáljuk a nitridált réteg korrózióálló tulajdonságait rozsdamentes acéloknál.

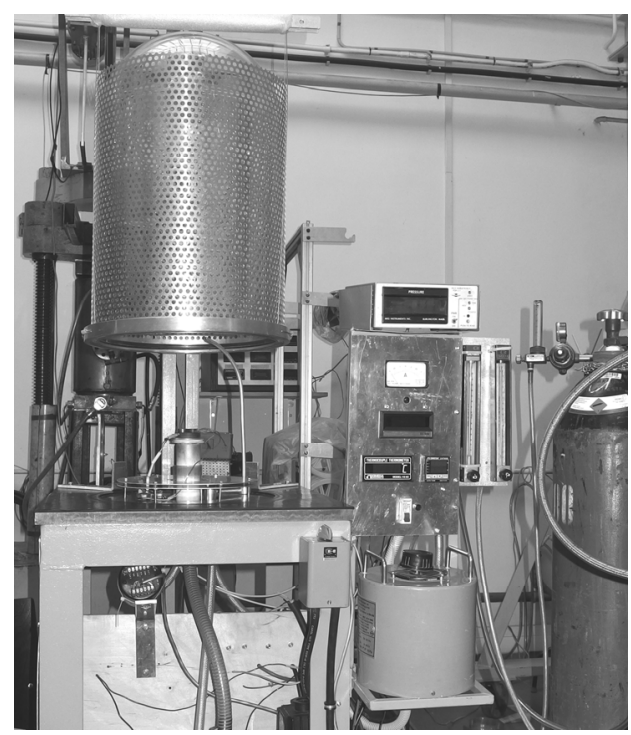

1. ábra. A saját épitésü plazmanitridáló berendezés

\section{Kísérletek}

Elsőként 25CrMo4 összetételü, nemesíthető acélok plazmanitridálásával foglalkoztunk. Mind ipari, mind laboratóriumi körülmények között végzett kezelés után megvizsgáltuk a keletkezett kemény réteg felületén kialakult vegyületeket és a rétegvastagságokat. A próbatest méretei mindkét esetben megegyeznek, $12 \times 20 \times 2 \mathrm{~mm}$. Az elemzések keresztcsiszolati mintákon végzett metallográfiai vizsgálattal kezdődnek, majd mikrokeménységméréssel, SEM-EDS és XRD-vizsgálattal folytatódnak.

Ezután a nagy hőmérsékleten nitridált rozsdamentes acélok elemzése, majd korróziós vizsgálata következett.

\subsection{Nemesíthető acélok}

A minták plazmanitridálása minden esetben 2,5 torr nyomáson, $80 \% \mathrm{H} 2$ és $20 \%$ N2 gázkeverék beadásával, $500-520^{\circ} \mathrm{C}$-on történt. Az ipari mintákat 12/24/40 órán keresztül, a laboratóriumi mintákat csupán 5 órán keresztül nitridáltuk. 
A különböző időtartamok a keménységet nem befolyásolják. A legkeményebb réteg 1620-1700 HV, az anyag belseje felé haladva pedig fokozatosan csökken, a fehér réteg vastagsága azonban már jelentősebb mértékben változik. A 12-40 órás kezelésekre nézve, a növekvő idővel egyre vékonyabb vegyületi réteg keletkezik. Hosszabb kezelési idő alatt a felület a folyamatos porlasztástól porózussá válik, ami az idő múlásával fokozódik (2. ábra). A rövid kezelési idővel készült mintadarabok átlagos rétegvastagsága $8 \mu \mathrm{m}$, azonban kedvezőtlen nitridháló (3. ábra) alakult ki a réteg alatt, ami elridegedéshez, későbbi repedések képződéséhez, majd töréshez vezethet.

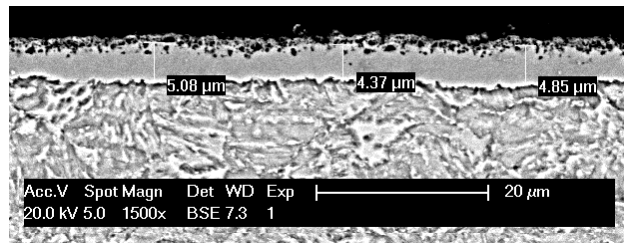

2. ábra. $25 \mathrm{CrMo} 4$ acélon $40 \mathrm{~h}$ után kialakult réteg

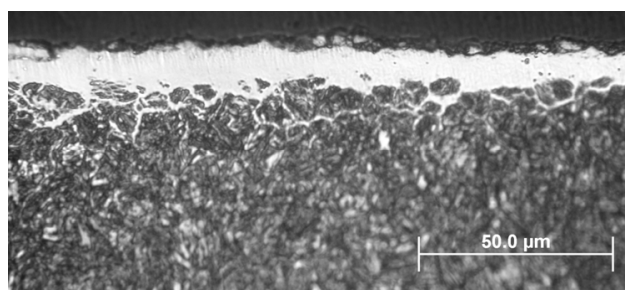

3. ábra. $25 \mathrm{CrMo} 4$ acélon $5 \mathrm{~h}$ után kialakult nitridháló

A diffraktométeres vizsgálatot $\mathrm{Cu}$-anód használatával Sajó István végezte; minden minta esetében kimutattuk a közel tisztán nitrides felületet (4. ábra).

$\mathrm{Az}$ első laboratóriumi mintánkon végzett diffraktométeres mérés eltérést mutatott az ipari mintákhoz képest. Nem csak vasnitrid keletkezett a felületen, hanem mellette különböző oxidok is megjelentek (5. ábra). Az oxidréteg kialakulása a vákuumtér nem kellő tisztaságából fakadt.

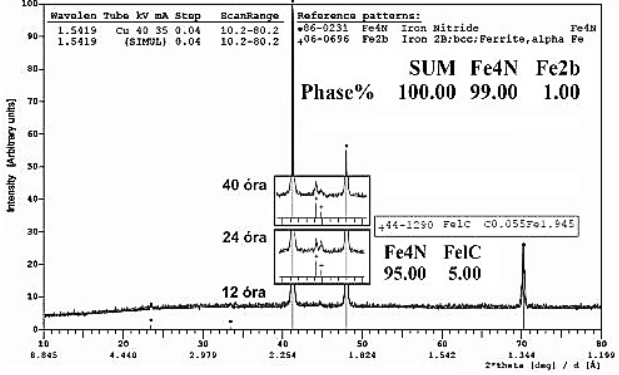

4. ábra. 25CrMo4 acélon 12, 24, 40 h kezeléssel létrejött réteg röntgendiffraktogramja

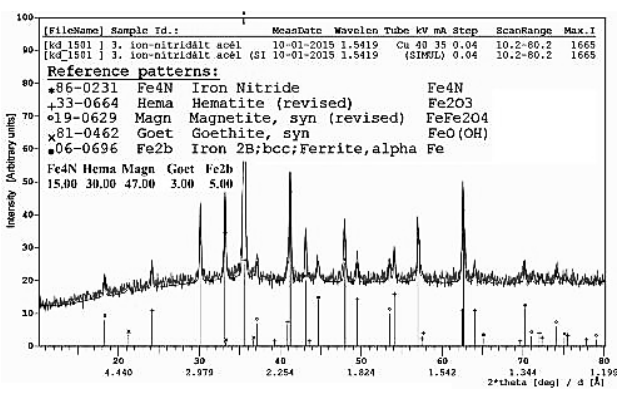

5. ábra. 25CrMo4 acélon 5 h kezeléssel létrejött réteg röntgendiffraktogramja

\subsection{Rozsdamentes acélok nitridálása}

$\mathrm{Az}$ ausztenites korrózióálló acéloknak kicsi a keménységük és csekély a kopásállóságuk. Kis hőmérsékletű nitridálással $\left(\leq 450^{\circ} \mathrm{C}\right)$ növelhető a keménység és a kopásállóság anélkül, hogy a korrózióállóság romlana [4]. A nagy hőmérsékletü kezelésre programozott kemencében kétféle acél niridálását végeztük el a Böhler-Uddeholm üzemében: egy ausztenites rozsdamentes acélt - 1.4301/ X5CrNi18-10 - és egy duplex acélt - DX2202/X2CrNiN22-2 kezelve.

Míg a metallográfiai vizsgálatokhoz a $25 \mathrm{CrMo} 4$ acélnál a vegyületi réteg maródott, addig a rozsdamenteseknél a diffúziós zóna mutatható ki. Három marószerrel dolgoztunk: Kalling, Beraha, Nital. (6. ábra).

A diffúziós zóna vastagsága mindkét esetben jól mérhető, $\sim 100 \mu \mathrm{m}$. A vegyületi réteg ezzel szemben alig látható, keménységméréssel is nehezen meghatározható. 


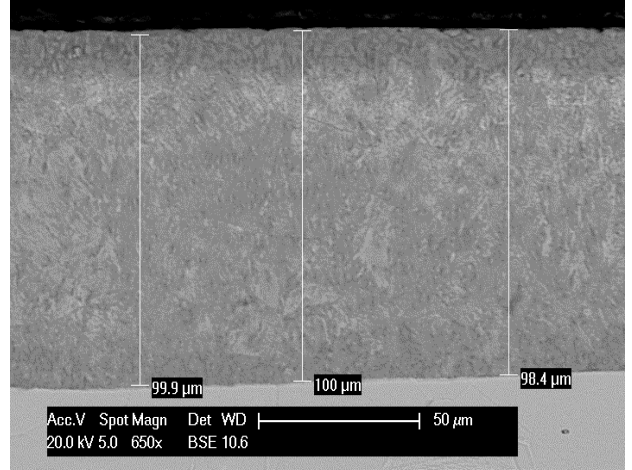

6. ábra.40 órán keresztül plazmanitridált 1.4301 acélon kialakult réteg metszete

A korróziós kísérletet a rozsdamentes anyagokra jellemzően, a lyukkorrózió körülményeinek megfelelöen végeztük el az ASTM G-48-as szabványnak megfelelöen 6\%-os vas(III)-klorid oldatban. A minták a plazmanitridálás után valóban elvesztették a korrózió védelemmel szembeni tulajdonságukat. A nitridált réteg a közeg hatására berepedezett, mechanikai erő hatására levált, letöredezett róla (7. ábra).

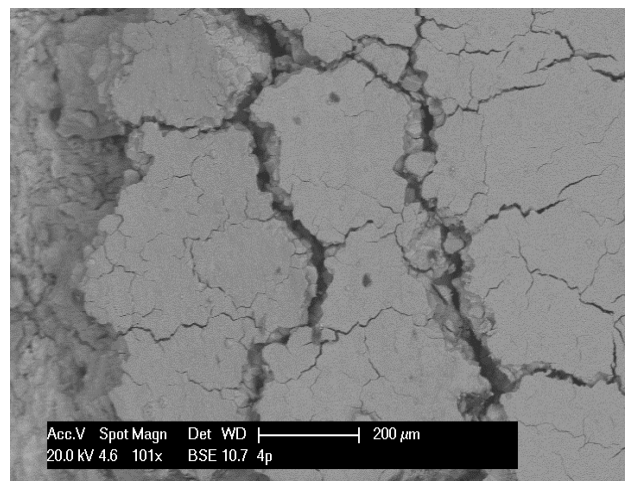

7. ábra. A plazmanitridált ausztenites acél korróziós teszt utáni repedezettsége

A csiszolati mintán jól látszik, hogy a levált nitridréteg alatt a korrózió az alapanyagot is megtámadta; a porózus rétegen keresztül az alapanyaggal is könnyen érintkezett a közeg (8. ábra).

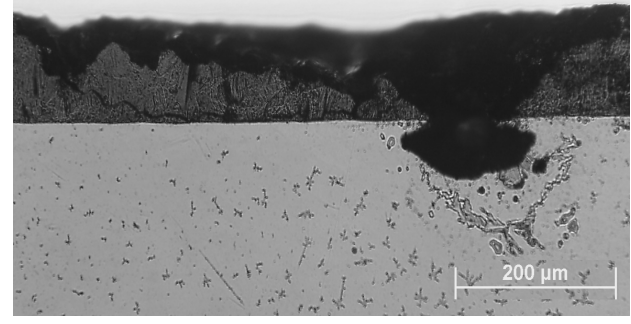

8. ábra. A nitridréteg alatti lyukkorrózió

\section{Következtetések}

$\mathrm{Az}$ eddigi kutatási eredményeinkből megállapíthatjuk, hogy a fehér réteg kialakulása már rövid ( 5 óra) idejü kezelés során is végbemegy, ugyanolyan keménységü réteget hozva létre, mintha tovább kezelnénk a felületet. A réteg vastagsága azonban nem ugyanolyan: az idő növekedésével a rétegvastagság is növekedik.

\section{Szakirodalmi hivatkozások}

[1]Pye D: Practical Nitriding and Ferritic Nitrocarburizing, ASM International, $\mathrm{OH}$, 2003, 71-86. oldal

[2]Edenhofer B: Production ionnitriding. in: Unterweiser PM (szerk.): Source book of nitriding. American Society for Metals, Metals Park OH, 1977. 181-187. oldal

[3] Marchev K, Cooper CV, Blucher JT, Giessen $\mathrm{BC}$ : Conditions for the formation of a martensitic single phase compound layer in ion-nitrided $316 \mathrm{~L}$ austenitic stainless steel. Surface and Coatings Technology, 99 (1998).

[4] Kimiaki Nagatsuka, Akio Nishimoto, Katsuya Akamatsu: Surface hardening of duplex stainless steel by low temperature active screen plasma nitriding. Surface \& oatings Technology 205 (2010) S295-S299.

[5] Constant A, Charbonnier J-C: Principes de base des traitements thermiques, thermomécaniques et thermochimiques des aciers. PYC Edition, Paris, 1992.

[6] Szombatfalvy Á: A hökezelés technológiája. Müszaki Könyvkiadó, Budapest, 1985.

[7] Edenhofer B: Production ionnitriding. in: Unterweiser PM (szerk.): Source book of nitriding. American Society for Metals, Metals Park OH, 1977. 181-187. oldal 